\title{
Critics, Politics, and Cultural Legitimation: \\ An Exploratory Analysis of the Turkish Film Field
}

\author{
Ozgur Yaren 1 Irmak Karademir-Hazır2
}

\begin{abstract}
In this paper, we draw on the growing Euro-American literature on cultural recognition, legitimacy, and film criticism and focus on the classificatory struggles taking place in the Turkish film field. We content-analyze the criteria that critics deploy as they review films as recognized by different institutions and actors. Multiple correspondence analysis (MCA) demonstrates that the distinction between artistic and commercial films is still very prominent. Moreover, the existence of political content in a film elevates its symbolic status, regardless of its production mode. To account for this peculiar finding, we explore a fraction of the reviews qualitatively. Our research contributes to the cultural legitimacy literature by crosschecking the effectiveness of recently posited trends and questioning the role of politics in the process of critical recognition in a specific national context located on the margins of Europe.
\end{abstract}

\section{Introduction}

Drawing on extensive theoretical and empirical investigation, cultural sociologists today agree that the value and quality of any artwork is not intrinsic (Becker, 1982). Cultural laudatory discourses in the form of consecration (Allen and Lincoln, 2004) or legitimation (Baumann, 2007a) participate in the process of creating the meaning of a work of art. As evidenced in the recent trajectory of the film field, the legitimation process not only defines hierarchical boundaries within a cultural field but also validates a particular cultural form by elevating it to the status of 'art' (Bauman, 2001).Critics play a major role in this process since they work as cultural intermediates between the artwork and the audience. This is why there is a growing literature systematically analyzing critics' perspectives and the potential implications of their evaluations (Janssen et al., 2011; Kersten and Verboord, 2014; Purhonen etal.,2017;Varriale, 2016).

\footnotetext{
1 Dr., Ankara University, Turkey.

2 Dr., Oxford Brookes University, UK. Both authors contributed equally to this manuscript.
} 
However, recent changes taking place in the broader field of culturehave raised significant questions regarding the role of critics and the current status of the traditional tension between commercial films and art films. New trends within the film industry, the rise of the cultural omnivore, and the growth of online amateur criticism challenge the dynamics of the validation and legitimation procedure. In this context, there is a need for a thorough investigation of the ways in which hierarchies within the field of film are established and legitimized through the institution of film criticism.

A number of recent empirical studies have exploredthe changing classifications in film by focusing on film critics, and they have been influential in the various conceptual and methodological decisions made in this paper (Allen and Lincoln, 2004; Kersten and Bielby, 2012; Kersten and Verboord, 2014). In this literaturerecommendations are often made for further studies investigating cultural validation processes in different national contexts. Based on this suggestion, we focused on film reviews published in the printed media in Turkey 2015 and content-analyzed the criteriathat critics deploy. We also questioned how these criteria relate to the reviewed film's position within the field of film in general. Our research makes an important contribution to the literature on cultural legitimacy by crosscheckingto what extent the recently posited trends, such as the narrowing of the distinctions between high vs. low culture and art vs. commercial, are effective in the field.It also introduces some important new aspects, such as the role of critical political content in the process of gainingrecognition, which is a significant finding when contextualized into the increasingpolarization of the cultural field, which escalated in the period under study in Turkey.

Following a review of the literature, we will provide a background for the field of film and culture in Turkey. We will then introduce the methods employed in the sampling, coding, and data analysis. We will map the componentsthat reviewers deploy by using multiple correspondence analysis (MCA) and then, by drawing on extracts from the reviews, we will focus on the role of political content in the process of critical recognition. We will close by locating the significance of our findings within the wider literature. 


\section{Recognition in theField of Film}

Cultural legitimation operates in complex ways, manifesting similarities as well as differences in different times and national contexts. Bourdieu suggests that it has three primary forms: "specific" legitimacy (maintained by other cultural producers), "bourgeois" legitimacy (granted by agents and institutions of the dominant class), and "popular" legitimacy (based on public acclaim) (Bourdieu, 1993:50-51). In their influential work, Allen and Lincoln (2004) operationalized these forms in relation to the field of film and introduced three main types of recognition: professional, critical, and popular. Professional recognition is bestowed by other artists and filmmakers through specific institutions such as films festivals and awards. Critics and film scholars are the main agents for the critical recognition of films. Audience attendance and box office figures as reliable statistical indicators represent popular recognition and thus the legitimacy of films as cultural products (Allen and Lincoln, 2004: 879-880).

These recognition mechanisms have a complex interaction with existing hierarchies within the film field, conforming, transforming, and at times rendering them obsolete. The most commonly recognized tension in the field of film stems from the distinction between commercial cinema in the entertainment sector and art cinema, a certain specific variant of films being of "cultural importance" and "national films of quality" (Ellis, 1978:12; Neale, 1981). In the former, the aim is to reach the widest possible audience and maximize the economic return,while in the latter it is to accumulate symbolic capital and generate artistic value (Bourdieu, 1993;Kersten and Verboord, 2014). It is important to note that "art cinema"refers to both a historically specific term (a distinct post-war European film practice against Hollywood domination) and a wider term defining all efforts of deviation from classical narrative cinema. However, in either case, art films tend to be marked by a stress on a distinct visual style, and character over plot and action. Moreover, they tend to prefer interior dramatic conflicts rather than chains of exterior events (Neale,1981:13).

The symbolic value of art cinema wascontested by auteur theory during the 1960s and early 1970s. This theory assigned a director/scenarist role to the director, appreciating the directing styles that go beyond just staging a script. Although partially utilized to challenge European art cinema, auteur theory, as it was coined in the 1950s in the French film journal Cahiers $d u$ 
Cinema, also gainedhigh artistic valuewith time. Film validation circles and institutes of consecration (international film festivals, retrospectives, film scholars, critics, etc.) have increased the perceived prestige of the director/scenarist role (Bordwell, 1979:59).

The tensions within the film field are in a complex relationship with the type of recognition that film products receive. It is hard to find any direct association between recognition mechanisms and the traditional hierarchy that exists between art vs. entertainment. As referred to above, critics influenced by auteur theory tend to validate certain popular films due to the personal touch of the director, or, as suggested by Kersten and Verboord (2014), certain films that are not primarily produced with commercial motivations do gain popular recognition through box office numbers (e.g.,Lost in Translation).The explanatory power ofthe 'art vs. commerce' dichotomy over the tensions operating in 21 st century cultural industries is found to be highly questionable.(Heise and Tudor, 2007; Prior, 2005; Tudor, 2005).In fact, it seems that sociopolitical features in a given national context tend to affect the mechanisms of legitimation and render these grand categories less relevant. For instance,Lavie and Dhoest (2015) compare the quality TV discourses in Flanders and Israel and find that Israel's turbulent political atmosphere affects the criteria employed to define 'quality' in cultural production and appreciation. Whileuniversal themes are hailed in the Flemish context, social and political subversion add value to cultural products in Israel. This 'courageous' content can be about various sociopolitical issues: capitalism, socioethnic inequalities, male chauvinism, Israel's treatment of the Palestinians, etc. (Lavie, 2015). We consider this finding highly relevant for our analysis, given the sociopolitical turmoil and polarization Turkey witnessed in the recent decades. We will unpack this issue more as we give more details about the qualities of the film field in Turkey later on. Now we will move on to unpacking some recent trends likely to affect the complex interlinkages between recognition processes and the institution of film criticism.

\section{Recent Trends and Film Criticism}

In post-war Europe, cinema, which is fundamentally a lowbrow entertainment field, despite the experimental and modernist niches it accommodates, developed a culturally legitimate form of itself. Starting from the 1950s, a distinct mode of film practice, namely art cinema, constructed itself by "possessing a definite historical existence, a set of formal conventions, and implicit 
viewing procedures" (Bordwell, 1979:56). Through its various aesthetic strategies, open-ended narratives, psychological causation, realism, authorial expressivity, stylisms, and ambiguity, derailing from classical narrative cinema enabled a multi-level reading of art films. This in turn created an intellectualizing discourse around cinema. The intellectualization of film discourse by professional critics played a major role in film's cultural ascendancy(Bauman, 2001; Kersten and Bielby, 2012). From the 1960s onwards, film criticshave used a new vocabulary and reviewing style that is more common to high art worlds. Reviews decode filmic elements including the story, acting, and techniques of cinematography.Critics also "began to interpret films for their messages or meanings", which "framed films as art within the established ideology of art as a form of communication between an artist and an audience" (Baumann, 2007a:59). For instance, film reviews began to focus on the role of the director as the driving creative force in filmmaking (Baumann, 2007a:59), showcasing the influence of auteur theory.As demonstrated by the crossnational and longitudinal studyof Janssen et al. (2011), Baumann's findings (2001)have wider resonance across Europe.While the attention paid to directors who function as the dominant creative talent behind productions increased over time, the number of articles on adaptations and remakes has declined noticeably (Kersten and Janssen, 2016).

This intellectualizing discourse and style of review not only legitimized film as art, but also established a hierarchy with the genre. Baumann's study (2001) reveals that, in their validation of films, critics use certain parameters to separate art films. Critics seem to distinguish the 'serious' from the 'commercial' and 'artwork' from 'entertainment products'. As they criticize certain films for being 'easy' or lacking subtlety, they attach value to the characteristics of films, including the story, cinematography, directing, and acting. Furthermore, there seems to be a systematic difference between the aspects reviewed by critics (the types of emotions the film generates vs. the language of the director) and the type of recognition films get (Kersten and Bielby, 2012). These evaluations reinforce and reproduce the positions of large-scale productions (primarily prioritizing wider audiences) and small-scale productions (prioritizing artistic value).

However, systematic longitudinal studies suggest that there aregradual distinctions and fuzzy boundaries. For instance, Kersten and Bielby (2012: 196) find that the reviews of films that achieve popular and critical recognition "share many of the same substantive considerations", 
demonstrating "that film criticism is not bound by a strictly detached or pure gaze even as film has become a more elite art form". A similar finding can be derived from Kersten and Verboord's (2014) cross-national analysis of the current film recognition dynamics. Their study demonstrates the continuing effect of the blockbuster vs. art house dichotomy, but they also show that the "distinction proves to be a gradual slide from conventionality to innovation" (p. 15) rather than operating strictly.

Wider cultural trends influence the film field by altering established classifications. For instance, there is a growing literature in cultural sociology casting doubt on the current role of traditional highbrow culture and the exclusiveness of legitimate taste. (e.g.,DiMaggio and Mukhtar, 2004; Peterson, 1992; Peterson and Kern, 1996; Prieur and Savage, 2011;van Eijck and Knulst, 2005). The term 'omnivore', coined by Peterson, referred to a change in cultural repertoires from appreciating exclusivelyhighbrow genres towards being open and tolerant to new and popular tastes. This change taking place on the part of audiences had wider effects at field level as well, as evidenced by the legitimation of previously lower status genres such as jazz (Peterson, 1997, 2005; Peterson and Kern, 1996).Empirical studies suggest that the broadening of repertoires is observable in the case of film-viewing practices as well. For instance, Barnett and Allen (2000: 145) found that the upper middle class in the US draws on more eclectic repertoires and views “more 'art' films, as well as more 'classic' films and 'blockbuster' films, than members of the lower-middle class". The same trend is demonstrated clearly in the case of Flanders, Belgium. Roose et al. (2012: 504)found that tastes associated with entertainment (adventure, action, comedy special effects, and romance) were coupled with an "interest in movies with original direction and critical comments on society, which are characteristic for highbrow art movies".

It is also important to note that the boundaries between art films and Hollywood movies seem to have blurred in recent years. For instance,mainstream cinema and genre films are argued to embrace some tactics of art cinema (Andrews, 2013:XI). They also show more willingness to play with genre conventions and embrace novelties. As grand auteurs of Hollywood like Hitchcock did previously, some films combine formal principles from both classical narrative cinema and art cinema. Meanwhile, art films borrow marketing strategies from commercial 
producers in order to survive the increasingly tough economic climate of cultural industries (Drake, 2008). These trends have effects on the aesthetic and the commercial and serve to dissolve the boundaries between art and popular culture (Prior, 2005:132). However, recent studies suggest that these trends did not result in a decline in 'serious' cultural journalism, nor did they dramatically alter the hierarchies within the film field established by the application of high art principles (Heikkilä etal., 2017; Kerstern and Janssen, 2016; Verboord, 2014).

\section{The Field of Film and Recognition in the Turkish Sociopolitical Context}

The processes of cultural legitimation may operate differently in the Turkish case due to the characteristics of its film field and the way this field has been embedded in the sociopolitical structure. First, the tension between the popular and the 'legitimate' can have a distinct status. Today it is argued that the distinction between commercial/entertainment value and artistic value has become less sharp than it used to be in earlier periods (e.g., Kersten and Bielby, 2012), due to many changes taking place in the audience repertoires and film production conditions. In the Turkish case, however, we can expect this distinction to maintain its explanatory power since films that receive popular recognition have very few overlapping qualities with the ones that receive critical and professional recognition. Turkey poses an exceptional situation in Europe as the larger portion of box office income goes to domestic productions, which are mostly sequels of 'lowbrow' comedies or feature film adaptations of TV serials.Despite their unparalleled boxoffice success, these productions are dismissed and disdained because of their tasteless quality. The most noteworthy case has been the Recep Ivedik sequels, aseries of films written, starred in, and produced by comedian Şahan Gökbakar. Four out of five films in this series made it into the list of the top ten highest grossing films in Turkish cinema. "Without a major star other than Gökbakar, for whom this was a first leading cinematic role-, a large budget, any special effects, or a traditional promotional campaign", the first film of the series reached over 4 million viewers and the last one 7.4 million viewers in Turkey (Behlil, 2010:6). However, because of the main character's vulgar manners, gross habits, and dirty jokes, this series has created controversy (Suner, 2011:139). The criticism it receives is not limited to only the

juvenile physical comedy that it embraces; it also targets the profound political incorrectness of the series. Thanks to its sexist and homophobic references, and its careful play with national and 
lower class identity, where "the element of self-mockery can easily turn into self-celebration" (Suner, 2011:125) and thus become nationalist, the Recep Ivedik series is found to be politically incorrect by many critics and scholars. Another adaptation from TV, KurtlarVadisi: Irak(Valley of the Wolves: Iraq)(Serdar Akar, 2006), featuring a Mafioso hero fighting conspiracies against the Turkish nation, shares similar critical dismissal despite huge boxoffice success thanks to its blatantly nationalist, militarist, and sexist discourse.Even in the context of a larger trend towards 'cultivated' repertoires opening to popular selections, these domestic films with high commercial value in Turkey are generally not appreciated by critics or by holders of high-brow and/or omnivore repertoires.

Second, the political position being taken with a cultural product, as evidenced by the plot, the selection of actors, and the alignment of the director, may influence its legitimation more directly in the Turkish case than in the other contexts studied so far. As Lavie and Dhoest's study (2015) demonstrated, unlike in the case of Flanders, politically subversive content elevated the status of cultural products in Israel, where the political and cultural field has been more polarized than in Flanders. A historical perspective would likewise show that the sociopolitical processes in Turkey have shaped the film field quite directly as films, filmmakers, and critics were expected to contribute to the construction of a 'national culture'after Turkey's modernization and its struggle to break away from the Ottoman past began. As Robins and Aksoy (2000) suggest, in the early years film censorship commissions regulated by the state aimed at the 'protection and the projection' of a national culture by banning any content that would damage the national regime or harm national sentiments. This commission, labeled as 'film guardians of Turkish national identity' by Robins and Aksoy, banned hundreds of films and documentaries that were considered to misrepresent the Anatolian people or be harmful to national customs due to a focus on various issues ranging from class exploitation to societal conditions in Kurdish regions. Thus, the political position-taking of films not only affected what was considered to be worthy of public support in the form of funding but also determined which productions couldbe distributed at all. Given the way in which the film field was embedded in politics, it is difficult to consider any aesthetic legitimation process operating autonomously up until the 1980s, when direct censorship was abolished. Since the 1980s, there has been a proliferation in the topics covered by Turkish cinema, especially in the form of 'personal identity' themes, which demonstrates the plurality and the clash of gender and ethnic identities in urban settings. Many of these films, such 
as Yeşim Ustaoğlu's Güneşe Yolculuk (Journey to the Sun)(1999) or Emin Alper's Tepenin Ardinda (Beyond the Hill) (2012), have received awards at national and international festivals, granting them professional recognition. Critical political content, which once determined which films could be screened, began to circulate more freely, imbuing some productions with a different value in addition to the commercial and the artistic.

Polarization in the political field has intensified gradually since the 2000 s, which we believe has given a different status to the 'political value' mentioned above. Given the trajectory of the interaction between the political and the cultural, our data collection point in 2015 makes the impact of this interaction on legitimation processes more visible. In its first years in power, beginning from 2002, the Justice and Development Party (AKP)asserted its goal as conservative democracy, which is almost indistinguishable from liberalism in terms of multicultural reconciliation,the defenseof liberal market values, and positioning itself against socialism (Birdal, 2015:52). In these first years in power, the AKP benefited from wide social legitimacy whereby conservatives, Islamists, liberals, and liberal democrats enjoyed companionship for the first time against hardline Kemalist nation-state ideals and exclusionary identity politics. The 2000s also witnessed the consolidation of democratic values, hopes for joining the EU, relative economic stability, and optimism, which led to a thriving cultural industry, an increased number of film festivals, and a boom of young filmmakers, almost exclusively funded by the Ministry of Culture.

Meanwhile, over the years, Islamist column writers were complaining that the film field was under the hegemony of leftist, socialist, and Kemalist circles who disregarded and marginalized Islamist, conservative filmmakers (Aydemir, 2015:407). This fit the popular Islamist narrative of discrimination bya secular Kemalist elite holding power in society.Secular fractions have in fact had a dominant position in the field of cultural legitimation and thus the centralization of power in this sense has been disproportionate. Film production, along with media outlets, daily newspapers, and film journals, are all based in Istanbul, the de facto cultural capital of Turkey. As is the case in other national film cultures, prominent Turkish filmmakers, actors, actresses, festival curators, and film critics tend to embrace humanitarian, liberal, progressive, or left wing ideology, befitting a multicultural urban environment. As Islamists consolidated their power and 
endorsed a conservative and gradually Islamic lifestyle, a huge antagonism flourished in the cultural field.

Fed by this antagonism, newspaper interviews and award ceremonies became an oppositional platform for film circles to manifest their dissidence. The Film Critics Association Awards attracted media attention, particularly through the dissident messages of contributors on the awards ceremony stage. Occupying a subordinate position in the cultural field, including film production, and not being able to claim critical and professional recognition triggered a feeling of discontent among conservative fractions, which endured even after the conservative/Islamist AKP came to power and gradually consolidated its hegemony over society to the extent of decisive totalitarianism. Islamist opinion leaders have explicitly complained about this weakness and its persistence despite the power that they hold in every other social field. For instance, conservative writer and academic İskender Pala complained about the government's failure to represent the identity of conservative Islamists at artistic events: "In this country, conservatives have become affluent, bosses, scientists, and they even came into power, but they fail to claim their [own] culture" (Pala, 2009). Supporting this observation, in an interview, the Nobel Prizewinning novelist Orhan Pamuk observed that "maybe Turkey has an Islamist conservative government, but on the other hand, they are not culturally that powerful. Culture is represented by—I wouldn't say the left, but definitely by the secularists"3 (Aksoy \& Şeyben, 2015:192).

However, the vibrant cultural environment enjoying the optimism of the 2000s has been quickly reversed in recent years. As Aydemir (2015: 404) suggests, "after 2010, the ruling AKP has abandoned claims of liberalization and democratization whilst undertaking 'social engineering' practices, which also led to a process of reformation in the field of cinema". The tension between Islamist and secular fractions intensified as the cultural politics of the AKP "steer the country's public culture towards a conservative position, in direct opposition to the established instituted secular cultural and identity" (Aksoy and Şeyben, 2015:185). The AKP's hardline cultural politics aimed to encourage national (implying religious, as well) and family values under an

\footnotetext{
3OrhanPamuk on Taksim Square, the Effects of 'Breaking Bad,' and Why the Future of the Novel Is in the East,The New Republic, (30 July 2013), https://newrepublic.com/article/113948/orhan-pamuk-interview-taksim-squareerdogan-literature.
} 
invented, generic neo-Ottoman identity while suppressing dissident ideas and works. The film production support program that distributes public funding was reconfigured accordingly, forbidding funding access for politically critical filmmakers. For instance, at the 2014 Antalya Film Festival, Reyan Tuvi's film (Yeryüzü Aşkın Yüzü Oluncaya Dek) was banned from screening. Following this, Çayan Demirel and Ertuğrul Mavioğlu's propaganda-style documentary (Bakur) was excluded from the program of the prestigious International Istanbul Film Festival in 2015.

Particularly following the Gezi Park demonstrations4 in the summer of 2013, insistent attempts to impose a conservative culture and lifestyle, and its increasing intolerance towards the democratic demands of citizens, have reshaped the public sphere (Aksoy and Şeyben, 2015:185). The increasingly authoritarian and oppressive tone of the regime has left virtually no room for oppositional media and gradually anything but blunt propaganda press. The crackdown on journalism naturally first hit newspapers with highbrow readerships, typically with limited circulation numbers and a failure to conform to the ruling party's ideological stance. Among those newspapers, many regular film critics lost their jobs or had to begin writing for emagazines and websites. This trend gained momentum at a shockingly fast pace: one of the newspapers included in our research has been shut down due to lack of circulation (Radikal), while a dozen journalists of Cumhuriyet (the oldest national newspaper) were put into prison under dubious accusations. Meanwhile, more than 400 Turkish film industry professionals and film critics have been subjected to investigation with allegations of praising criminals and crime on the basis of their declared support for an initiative called "academics for peace" 5 . The first sanction of this crackdown was to cut all funds to critical filmmakers. The periodin which we

4 The Gezi Park protests were described to the international reader by TheGuardian as follows: "Arguably the largest wave of protests in recent Turkish history, [where] hundreds of thousands took to the streets to contest the proposed demolition of an inner-city park in order to make way for an Ottoman-style shopping centre, a project pushed personally by then prime minister (and current president) Recep Tayyip Erdoğan. The government's uncompromising stance - and a heavy-handed police crackdown on demonstrators - prompted protests across Turkey, turning the local effort to save the park into a nationwide revolt against the increased authoritarianism of the country's leader and his Justice and Development, or AK, party”,The Guardian (29 April 2015), https://www.theguardian.com/world/2015/apr/29/gezi-park-protest-trial-turkish-court-acquits-all-26-defendants

5 Barış akademisyenlerinedestekveren 433 sinemacıyasoruşturmabaşlatıldı, Cumhuriyet (25 December 2016), http://www.cumhuriyet.com.tr/haber/turkiye/650504/Baris_akademisyenlerine_destek_veren_433_sinemaciya_soru sturma_baslatildi.html. 
collected our data, 2015, was a time when this tension in the cultural field was escalating and fostering the establishment of boundaries between artists, producers, and products in terms of their proximity to the conservative hegemonic project led by Erdoğan.

\section{Mapping the Film Reviews: Multiple Correspondence Analysis}

Our sample consists ofreviews published in three newspapers that employ professional film critics. These newspapers, Radikal, Habertürk, and Cumhuriyet, reach a large middle- to highbrow readership andthey all publish a review section regularly, which is not common practice in newspaper journalism in Turkey.

We conducted our study in 2016 and limited our sample to reviews of all movies released in 2015 that were validated through popular, peer, and critical recognition. As discussed above, classifications in the field of film and culture began to be more harshly contested especially after 2013, making the productions following this year excellent case studies to explore recognition dynamics. The top 20 films released in 2015 according to box office figures, regardless of being foreign or domestic productions, are considered as films with popular recognition. Winners and nominees of the Antalya Film Festival6, Academy Awards, and Cannes Film Festival7 were labeled as professionally recognized films. The 20 films awarded by theTurkish Film Critics Association in 2015 were taken to representcritical recognition. Our overall sample size is 878 reviews.

Before developing our coding scheme, we consulted studies in which film journalism is contentanalyzed (Kersten and Bielby, 2012; Kersten and Verboord, 2014). Inspired bythose studies, we inductively analyzed each review by creating new codes, altering and deleting them in the actual coding process. Appendix 1 lists and explains the 17 codes we found in our analysis.

In order to explore the relationality embedded in these codes, we use MCA. Its logic is similar to that of principal component analysis, but it uses categorical variables instead of numerical ones

6The oldest and most important annual national awards for particularly mainstream domestic films.

7 These are not just globally the most prestigious awards; they are also the most effective evaluation circles for determining films to be released in the domestic market.

8 As seen in Bourdieu's study on the publishing field (1999), MCA can be successfully used for analysis with small sample sizes. 
(Greenacre and Blasius, 2006). This visual and exploratory technique has been utilized in many Bourdieusian cultural field analyses (Bennett et al., 2009; Roose etal., 2012) since its inductive approach does not require the researcher to identify any independent variables prior to the analysis. The visual outputenables us to see which review components/codes are more likely to be, or unlikely to be, referred to together. After the space is constructed, additional, supplementary variables are superimposed on the map, revealing how certain variables (such as type of recognition) are associated with the general tensions on the map.

We retained 17 variables and their 37 associated categories (modalities) for the analysis. MCA revealed a very strong first axis, explaining $47 \%$ of the whole variance within the data. Researchers using MCA are advised to look at the interpretability of the axes and how the eigenvalues decline (Le Roux and Rouanet, 2004, 2010). We chose to retain the first two axes for interpretation, which explain $71 \%$ of the whole variance in the data. Figures 1 and 2 display the modalities that contributed above average to axis 1 and axis 2 , respectively.

The first axis, the strongest opposition,distinguishesthe right side from the left. The left-hand side is characterized by modalities indicating references made to the film's position in the artistic field, the extent to which the director has explored the film's material, and whether or not the film received any awards. This side is also marked by reviews that have interpretative content and political perspective. The right-hand side of the map is marked by modalities indicating references made to the material elements of the film, i.e. its budget; a lack of interest in exploring its position in the art field; the director's previous works, i.e. auteurism; its award history;and interpretative narrative. The review components listed on the left-hand side seem to affiliate with reviews that employ complex analytical tools for consecrating certain films as opposed to the ones that are compatible with the review elements affiliated with mass culture.Therefore, the prime opposition in the film review field in Turkey seems to be between analytic/consecrating components and culture industry-related ones. 
Figure 1. First Axis and Recognition Forms as Supplementary Variable

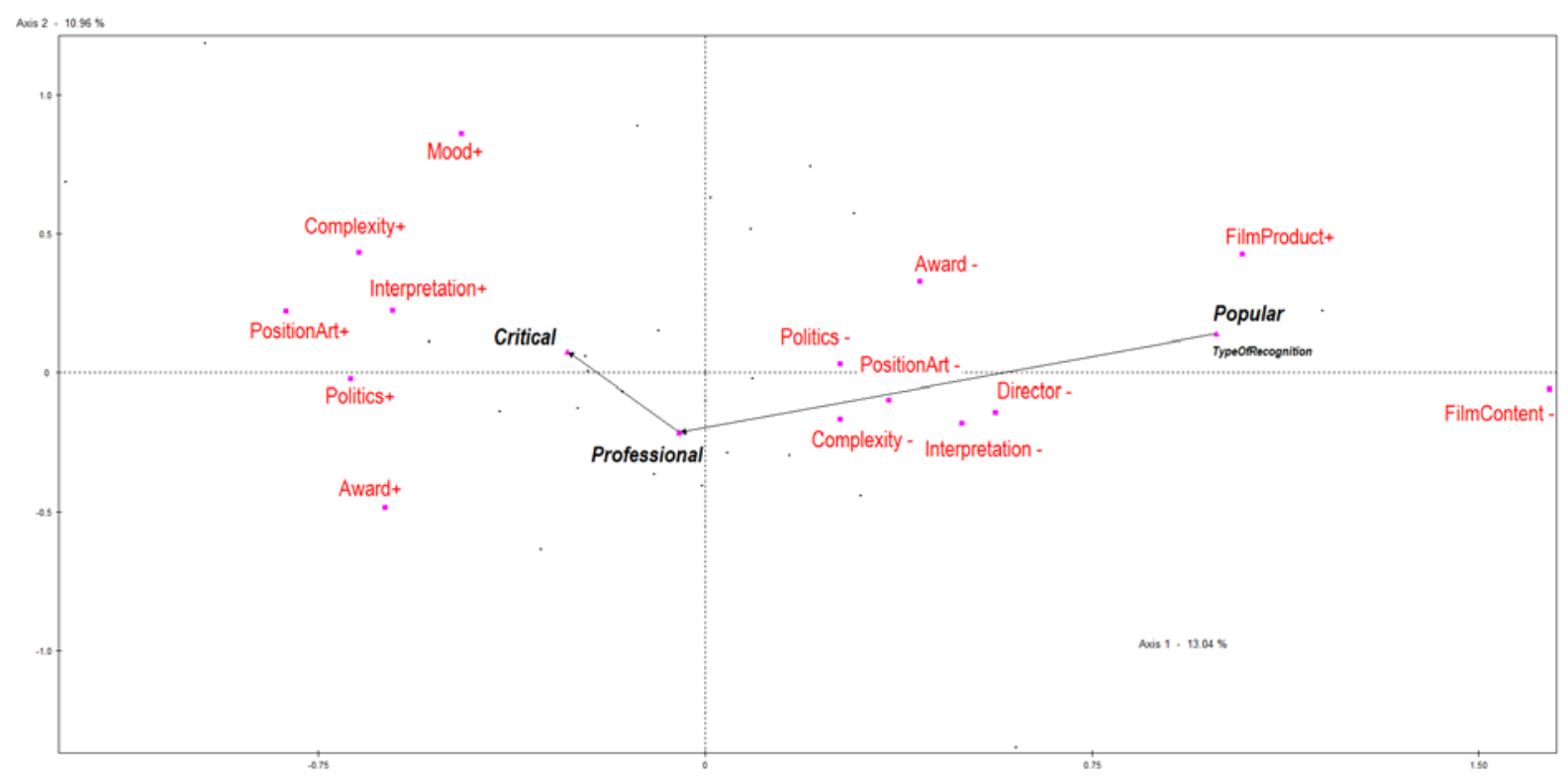

Figure 2. Distribution of Modalities: Second Axis

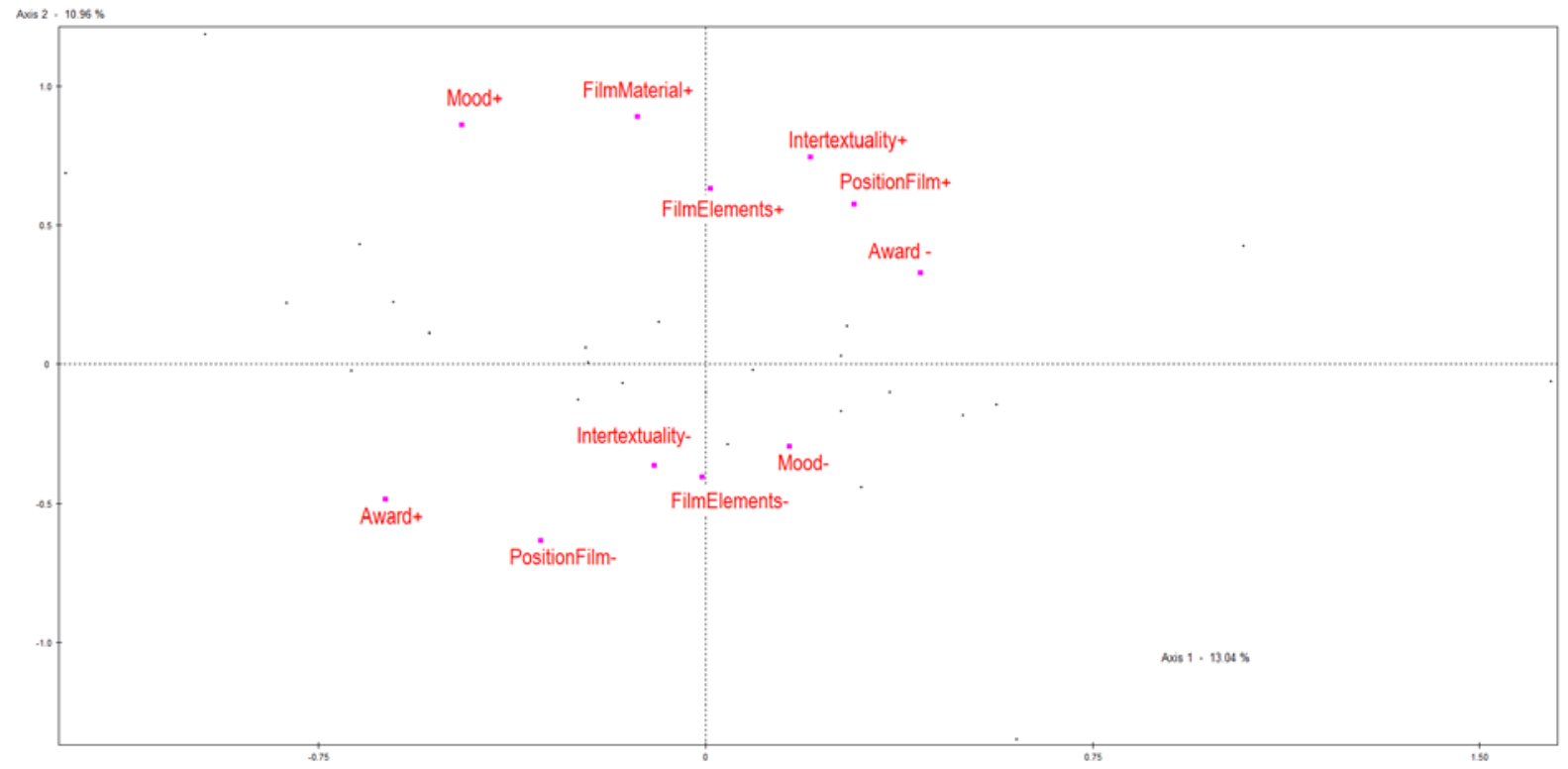


The second axis, which accounts for the second most powerful opposition in the data, distinguishes the upper and lower sides of the map. On the upper side, we have the modalities of quality of the screen play, technical aspects of recording, the film's linkages with other artworks, and the filmmaker's filmography or a certain genre. These modalities all refer to filmic and formal elements of the product. The lower side of the map is characterized by the lack of these references.

After qualifying the oppositions, we impose the types of recognition the reviewed films get as a supplementary variable. As Figure 1 demonstrates, the right-hand side (culture-industrial elements) is marked by popular recognition, whereas the left-hand side is marked by professional and critical recognition. It seems that differently recognized films get reviewed in specific ways. Critics are more likely to interpret/decode the layers of plots and to contextualize the product in the art field as they review critically and professionally recognized films. This practice imbues the products with cultural legitimacy, which is also reinforced by the awards given by critics and peers. The films that receive popular recognition and generate big box office revenues seem to be evaluated in quite different terms. Only the material elements of the production are recognized, suggesting that popularly recognized films are not approached and evaluated as artwork by the key figures in the field.

Our findings reveal that critical recognition operates differently in Turkey than reported in the studies reviewed above, which revealed a gradual positioning between popular (commercial) and artistic films (Kersten and Verboord, 2014). One can argue that MCA accentuates distinctions instead of showing overlaps since it is designed to highlight tensions within the data. However, the locations of the modalities (e.g.,FilmProduct+ next to negative values of artistic film qualities such as Complexity and PositionInArt) demonstrate the systematicity of the traditional distinction. Moreover, the relationality between different recognition types in our case seems to operate in a distinctive way. Critical and professional recognition types are located very close to each other and far from popular recognition. However, in Kersten and Verboord's study, professional recognition appears to work as a device blurring boundaries and enabling a continuous passage from popular to artistic films (Kersten and Verboord, 2014). The relationship between different institutions of recognition and the criteria critics deploy in Turkey is more in 
line with the distinction that Bourdieu (1993) makes between small-scale vs. large-scale film fields.

Another distinctive finding of our MCA map is the significant role that politicshas in the critical recognition of films in the Turkish context. Films receiving critiques in a political context, regardless of their position between art and the mainstream, tend to be positioned on the left side to the center of the map.It seems that the existence of political content facilitates cultural legitimacy by elevating the film to critical artwork status in the eyes of critics. This finding is in line with the contextual background provided above and reinforces Lavie and Dhoest's (2015)findings regarding the role of subversive content in defining 'quality' in politically polarized national contexts.

\section{The Role of Politics in Critical Recognition}

Our exploratory analysis demonstrated that, in the Turkish field of film reviews, the existence of political content is highly valued by critics. Especially in the reviews of critically and professionally recognized films, decoding the political message seems to be a key element. Given the lack of similar findings in the literature (with the exception of Lavie and Dhoest, 2015), we decided to investigate this peculiarityfurther. What kinds of political content are critics attentive to? Do any of the popularly recognized films receive critics' attention in terms of the political messagesthey convey? As discussed earlier, MCA allows us to inspect individual reviews qualitatively and enables us to explore these questions in line with our previous analysis. Figure 3 shows the locations of the movies we will revisit in this part. 


\section{Figure 3. Cloud of Reviews}

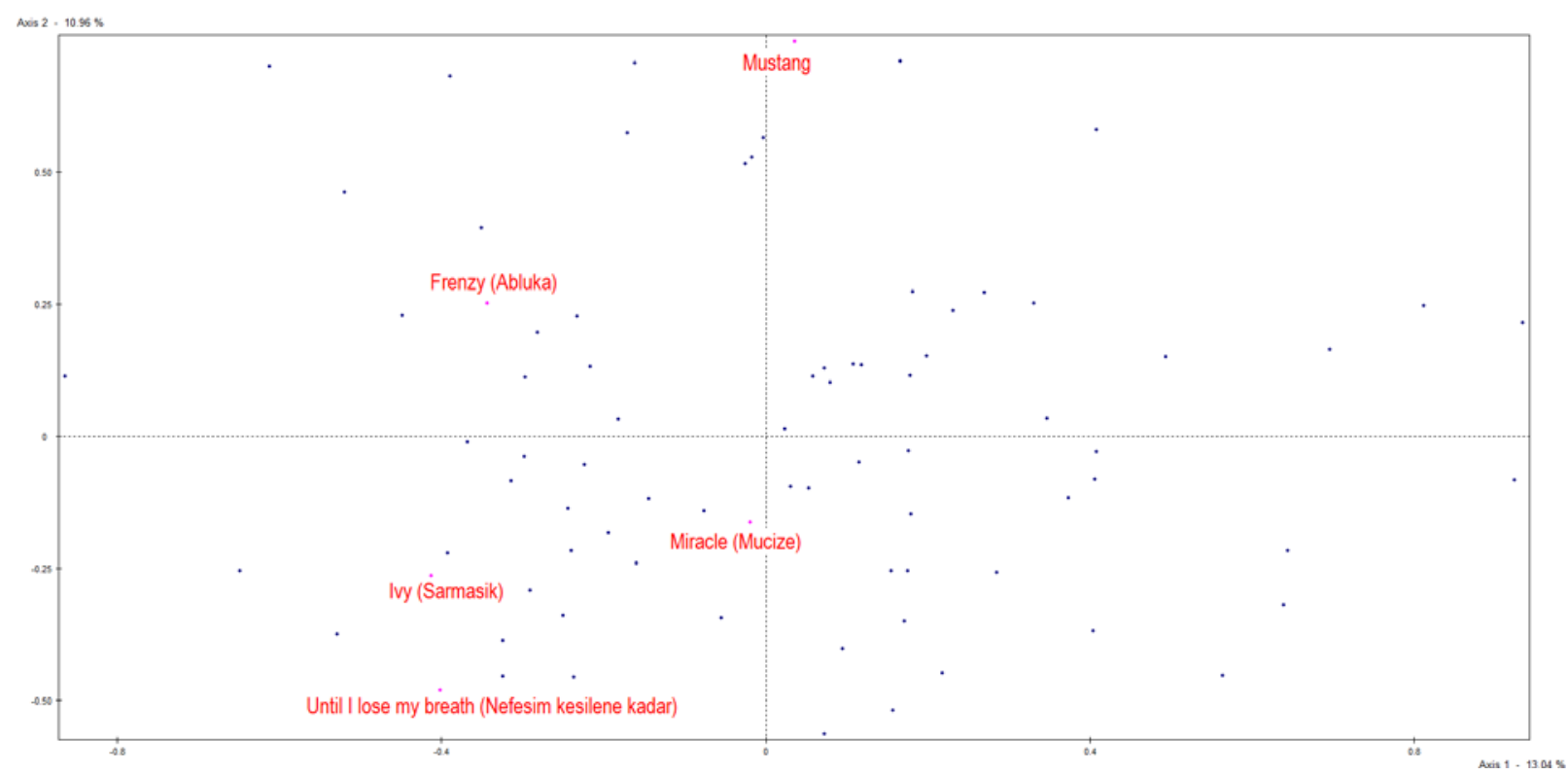

Abluka (Frenzy) is placed on the left-handside of our MCA map and its review deserves closer inspection since it demonstrates some of the most frequently referred to political content (state authority) in critically recognized films. With an admiring tone, Radikal'scritic stresses Frenzy's brotherhood theme andpositions the film with prominent literary and cinematic works such as The BrothersKaramazov and Rocco and His Brothers. He decodes this theme as"an impressive metaphor of today's Turkey", where a split in the feeling of brotherhood constitutes "our real problem". He also explains what lies beneath this theme:"An even ghastlier creature slowly moves in the background like a sea monster: The State. Frenzy is a perfect political Gothic" (5.11, Radikal).

Similarly, the current state of Turkish politics is referred to in the review ofSarmaşık(Ivy) published in Cumhuriyet. Located on the analytic/consecrating components' side of the first axis, Sarmaşık's review demonstrates how the director sets the plot (mutiny on a cargo vessel) as a national analogy representing the Turkish political scene. Here the reviewer also implies his own critical standpoint toa larger issue implied in the film: "What would a dysfunctional authority do to maintain the existing hierarchy?" This two-sided question works both as a suspense device in the plot (What will the captain do in the face of mutiny?)and as a political inquiry (How would the Turkish state maintain existing hierarchies in the face of vast social problems?)(17.9, Cumhuriyet). 
Interestingly, the existence of political content seems to elevate the status of the film in the eyes of critics. Critics seem to particularly enjoy political and national analogies, where the elements and characters of a simple plot actually represent greater facets of the social/political realm. While this is on par with the more universal trend of praising multi-layered works (Complexity/depth), which lets reviewers interpret works in an evaluative way (Interpretation), we observe that an analogy with political content strongly leads to criticalrecognition. We can observe that films of this sort are lodged on the left half of our MCA map (analytic/consecrated), where critical recognition is evident. This is even the case for popular films that would otherwise remain on the right side (cultural industry).

Our quantitative inspection suggests that popularly recognized films are more likely to be reviewed by giving reference to their production aspects. As we dig deeper qualitatively, however, we find that, especially in the case of domestic productions, reviewers are willing to engage with the political content that popular films deliver if, of course, they can identify a critical outlook. Mucize (Miracle) exemplifies this disposition clearly. It is positioned in the center of the map, but its political content places it slightly to the left. Mucize was produced and directed by Mahsun Kırmızıül, originally a pop singer whose artistic aspirations have been ridiculed by critics. However, Mucize was considered worthy of in-depth review by critics, mostly because of the political underpinnings of the plot:

There is a resemblance between Aziz's loneliness in the village and the loneliness of an eastern [i.e. Kurdish] town in Turkey. Deep down, Kırmizıgül underlines the fact that the state ignored Kurds and left them by themselves for decades... The sparing, understanding, and tolerant teacher representsexactly the opposite of the authoritarian state(1.1, Habertürk).

Critical political content has many facets, and as the review of Mustang (directed by D.G. Ergüven) demonstrates, in many cases these elements overlap and intersect. Its review underlines the political background, focusing on gender issues in a patriarchal and traditional society. Nevertheless, it celebrates Mustang in a general anti-authoritarian tone:"It is not hard to feel that Mustang is shot with a rebellious spirit. This film is a reflection of the anger towards paternalistic society and how it oppresses women in Turkey"(23.10, Habertürk). 
In addition to critical political allegories with anti-authoritarian content, plots challenging material inequalities and exploitative class relations are also positively valued and engaged with by critics. Nefesim Kesilene Kadar(Until I Lose My Breath), positioned in the lower left quadrant of the map, does not owe its critical recognition to being an overtly multi-layered story or political allegory:

Nefesim Kesilene Kadar accounts a young female textile worker's yearning for a warm home in a simple and realistic style...In domestic films and TV series, the only waylow incomepeople can be the leading character is to have an affair with someone from the upper class or to move up the social ladder. It is hard to come by films that try to observe and understand the working class in its own day-to-day reality(30.10, Habertürk).

The types of political content we have come across are not limited to these cases, but these cases demonstrate the contents most favored by critics. The most common political content is related to issues of ethnicity, class, gender, civil rights, and authoritarianism. This political content is not only referred to descriptively. Critics engage with these political aspects of the plot, often consecrating films through those critical contents. As is the case in national retrospectives and national film festivals, it is not uncommon to validate films for their representative value and adherence to certain political agendas, along with or rather than quality, value, or good taste (Czach, 2004:84).

\section{Conclusion}

In this study, we examined the criteria criticsuse as they review films recognized by different institutions and actors (professionals, critics, or audiences). There is wide consensus within the relevant literature on film's validation as art and the critic's role in this process. Theoretical and empirical analyses also seem to agree on the existence of two distinct value sets within the field with respect to what successful film production involves. Various debates within the recent cultural sociology literature, however,suggest that the lines between these two camps are becoming fuzzier than ever before. Critics have a role in reflecting and reshaping this tension between commercially motivated large-scale films and small-scale films that prioritize artistic value. Many inspiring studies trace such tensions within the film field by analyzing published 
film reviews. In this study, we aimed to engage with this literature by focusing on Turkey, a national context thathas not been studied so far from this perspective.

We employed systematic content analysis of the reviews published in three main newspapers and conducted MCA to visualize the prime tensions within the review components. MCA demonstrates that the distinction between artistic and commercial (mainstream) films still remains very prominent in the Turkish film field. Despite the growing literature on audiences become increasingly omnivorous (Peterson and Kern, 1996), contemporary film criticism incorporating aesthetic elements drawn from popular interests as well as elite art considerations (Kersten and Bielby, 2012), and distinctions tending to blur in a more gradual and discrete manner (Kersten and Verboord, 2014), the Turkish case presents a decisive dichotomy. Critics systematically distinguish between artistic and mainstream films and they deploy different sets of analytic elements for each category. The spread of modalities on the first axis demonstrates thatcritics treat popularly recognized films as mere products of cultural industry. On the contrary, theyemploy both analytic and consecrating review elements in their reviews of critically and professionally recognized films. This trend creates two distinct modes of film criticism; one stands out with filmic, formal references and the other significantly lacks those references. Critics play the role of "cultural intermediaries between artistic goods and audiences" (Kersten and Bielby, 2012: 184); thus, we can expect this traditional distinction between art and entertainment to have a wider resonance and a long-lasting impact in the Turkish film field.

MCA and the positioning of the supplementary variables (i.e. recognition types) suggest that the Turkish case differs from the national contexts studied with the same focus so far,especially in terms of the relationship between different institutions of recognition. The existing literature suggests that the boundaries between recognitions are blurring through professional recognition, which intermediates between critical and popular recognition (Kersten and Bielby, 2012; Kersten and Verboord, 2014). In our case, however, while professional and critical recognition approach each other, they significantly draw away from popular recognition. This empirical finding can also be supported with observational data. For instance, national awards and prizes, which constitute professional recognition in the film field, tend toexclude domestic box office hits and ignore popular recognition.This suggests that the distinctions established in the late 1960s 
between'national cinema' (highbrow) and 'people's cinema' (lowbrow) in Turkey seem to continue operating, albeit articulating a different discourse.

The most interesting characteristic of the Turkish caseis the role played by criticalpolitical content. In our case, the existence of critical national allegories with a political basis seems to elevate the status of the film, regardless of its production mode (mainstream, art house, or lowbudget debuts), in the eyes of critics. Even the domestic productions, which could be considered as popular, receive a different treatment if they focus on long-lasting societal problems and conflicts. As discussed earlier, this finding resonates withthe study of Lavie and Dhoest (2015) on 'quality TV' discourses, whichhints at the role of political content in the process of legitimation. This research suggests that "the view of political critique as a sign of quality is much more prominent among Israeli television reviewers than among their Flemish counterparts, who seem to highlight more 'universal' social themes at the expense of direct political engagement" (p. 72). Given Turkey's sociopolitical position, and drawing on our analysis, we suggest that this dynamic may be accentuated and may have wider resonance in culturally polarized and more authoritarian national contexts. In these cases, the 'intellectual' class, actors, scenarists, directors, producers, and critics are usually punished by censorship and lack of funding and at times may face legal charges. In this context, the political field and artistic field have a much more complex and conflictual relationship with each other, making the boundaries of 'artistic criteria' more permeable. In other words, subversive political content in these contexts is likely to imbue a work withpositive aesthetic value, resulting in the recognition of productions that have a critical approach towards the establishment.

That said, we are hesitant to rule out the possibility that politicsmay systematically affect critical and professional recognition, bestowed in the form of awards such as the Cannes Festival, in other national contexts. Instead, we are inclined to consider the relationship between recognition and politics as a topic deserving further empirical investigation. Especially now, with the rising polarization and authoritarianization observed in Europe and in the US, this complex relationship deserves even moreattention from those who are interested in the workings of cultural legitimation. 
Appendix 1: List of modalities

\begin{tabular}{|c|c|}
\hline Actors: Acting talent, persona & $\begin{array}{l}\text { Formal/filmic elements: Technical aspect of } \\
\text { recording }\end{array}$ \\
\hline $\begin{array}{l}\text { Complexity/depth: Layers in } \\
\text { the narrative }\end{array}$ & $\begin{array}{l}\text { Interpretation: Revealing the hidden } \\
\text { meaning/multiple layers of the film }\end{array}$ \\
\hline $\begin{array}{l}\text { Political background: Political } \\
\text { content }\end{array}$ & Mood:The tone of voice in which a story is told \\
\hline $\begin{array}{l}\text { Credibility: Believability of } \\
\text { plot and characters }\end{array}$ & $\begin{array}{l}\text { Novelty: What film offers in relation to other film } \\
\text { experiences }\end{array}$ \\
\hline $\begin{array}{l}\text { Director: Personal style, auteur } \\
\text { marks, filmography }\end{array}$ & $\begin{array}{l}\text { Position in art/entertainment: Comparative } \\
\text { assessment of artistic and entertainment value }\end{array}$ \\
\hline $\begin{array}{l}\text { Film as product: } \\
\text { Material/economic elements }\end{array}$ & $\begin{array}{l}\text { Position in film context/canon: Where a film stands } \\
\text { in a director's filmography, in a genre, in a national } \\
\text { context, or in film history }\end{array}$ \\
\hline $\begin{array}{l}\text { Film content:Issues addressed } \\
\text { in the film }\end{array}$ & Intertextuality: Linkages between other artworks \\
\hline $\begin{array}{l}\text { Film experience: Emotional } \\
\text { effects caused by the film }\end{array}$ & $\begin{array}{l}\text { Self-reflexivity: Linkages to film history and film } \\
\text { medium }\end{array}$ \\
\hline $\begin{array}{l}\text { Film material: Screenplay } \\
\text { elements and style }\end{array}$ & \\
\hline
\end{tabular}

\section{References}

Abluka[Frenzy] (2015) [Film] Emin Alper (dir). Paprika Films et al.

Aksoy, A. And Şeyden, B. Y. (2015) 'Storm over the state cultural institutions: new cultural policy direction in Turkey', International Journal of Cultural Policy 21(2): 183-199, http://dx.doi.org/10.1080/10286632.2014.890605

Allen, M. P. and Lincoln, A. E. (2004) 'Critical discourse and the cultural consecration of American films', Social Forces 82(3): 871-894.

Andrews, D. (2013) Theorizing Art Cinemas: Foreign, Cult, Avant-Garde, and Beyond, Austin: University of Texas Press.

Aydemir, Ş. (2015) 'Beyazcam'dan 'Yeşilcam' Çıkarmı?' in İnal, K. et al. (eds.) MarkaTakvaTuğra: AKP Döneminde Kültür vePolitika. İstanbul: Evrensel, pp 404-408. 
Barnett, L. and Allen, M. P. (2000) 'Social class, cultural repertoires, and popular culture: the case of film', Sociological Forum 15(1): 145-163.

Baumann, S. (2001) 'Intellectualization and art world development: film in the United States', American Sociological Review 66(3): 404-426.

Baumann, S. (2007) 'A general theory of artistic legitimation: how art worlds are like social movements', Poetics 35(1): 47-65.

Becker, H. (1982) Art worlds. Berkeley, CA: University of California Press.

Behlil, M. (2010) 'Close Encounters?: Contemporary Turkish Television and Cinema', Wide Screen, 2(2), http://www.widescreenjournal.org/index.php/journal/article/view/25/29

Bennett, T., Savage, M., Silva, E., Warde, A., Gayo-Cal, M. and Wright, D. (2009) Culture, class, distinction. London: Routledge.

Birdal, S. (2015) 'AKP İktidarındaİdeolojiveHegemonya' in İnal, K. et al. (eds.) MarkaTakvaTuğra: AKP Döneminde Kültür vePolitika. İstanbul: Evrensel, pp 48-57.

Bordwell, D. (1979) 'The Art Cinema as a Mode of Film Practice', Film Criticism 4(1): 56-64.

Bourdieu, P. (1999) Unerévolutionconservatricedansl'édition. Actes de la recherche en sciences sociales, 126127: 328.

Bourdieu, P. and Johnson, R. (1993) The field of cultural production: Essays on art and literature. Columbia University Press.

Constanze L. (2015) 'Gezi Park protest trial: Turkish court acquits all 26 defendants', The Guardian, (29.4.2015), https://www.theguardian.com/world/2015/apr/29/gezi-park-protest-trialturkish-court-acquits-all-26-defendants

Czach, L. (2004) 'Film festivals, programming, and the building of a national cinema', The moving image 4(1): 76-88. 
DiMaggio, P. and Mukhtar, T. (2004) 'Arts participation as cultural capital in the United States, 1982-2002: Signs of decline?', Poetics 32(2): 169-194.

Drake, P. (2008) 'Distribution and Marketing in Contemporary Hollywood', in P. McDonald and J. Wasko (eds).The Contemporary Hollywood Film Industry. Wiley-Blackwell, pp. 63-82.

Ellis, J. (1978) 'Art, Culture and Quality: Terms for a Cinema in the Forties and Seventies', Screen 19(3): 9-50.

Greenacre, M. and Blasius, J. (eds) (2006) Multiple correspondence analysis and related methods. Boca Raton: CRC Press.

Heikkilä, R., Lauronen, T. and Purhonen, S. (2017) 'The crisis of cultural journalism revisited: The space and place of culture in quality European newspapers from 1960 to 2010', European Journal of Cultural Studies, 1367549416682970.

Heise, T. and Tudor, A. (2007) 'Constructing (film) art: Bourdieu's field model in a comparative context', Cultural Sociology 1(2): 165-187.

Janssen, S., Verboord, M. and Kuipers, G. M. M. (2011) 'Comparing cultural classification', KölnerZeitschriftfürSoziologie und Sozialpsychologie, 63(51): 139-168.

Kersten, A. and Bielby, D. D. (2012) 'Film Discourse on the Praised and Acclaimed: Reviewing Criteria in the United States and United Kingdom', Popular Communication 10(3): 183-200.

Kersten, A. and Janssen, S. (2016) 'Trends in Cultural Journalism', Journalism Practice 1-21.

Kersten, A. and Verboord, M. (2014) 'Dimensions of conventionality and innovation in film: The cultural classification of blockbusters, award winners, and critics' favourites', Cultural Sociology 8(1): 3-24.

KurtlarVadisi: Irak[Valley of the Wolves: Iraq](2006) [Film] Serdar Akar (dir.) Pana Film.

Lavie, N. (2015). Israeli drama: constructing the Israeli 'quality'television series as an art form. Media, Culture \& Society, 37(1), 19-34. 
Lavie, N. and Dhoest, A. (2015) 'Quality television' in the making: The cases of Flanders and Israel', Poetics 52: 64-74.

Le Roux, B. and Rouanet, H. (2004) Geometric data analysis: from correspondence analysis to structured data analysis. Dordrecht: Kluwer.

Le Roux, B. and Rouanet, H. (2010) Multiple correspondence analysis: series quantitative applications in the social sciences. London: Sage.

Mucize [Miracle] (2015) [Film] Mahsun Kırmızı̈̈l (dir). Boyut Film

Mustang (2015) [Film] Deniz GamzeErgüven (dir). CG Cinéma et al.

Neale, S. (1981) 'Art cinema as institution', Screen 22(1): 11-40.

NefesimKesilene Kadar [Until I Lose My Breath] (2015) [Film] Emine Emel Balcı (dir). Prolog Film

Pala, İ. "Kültürel Meselelerimiz-1 BirÇatışmaZeminiOlarak Kültür,” Zaman, 20 Ekim 2009.

Peterson, R. A. (1992) 'Understanding audience segmentation: From elite and mass to omnivore and univore', Poetics 21(4): 243-282.

Peterson, R. A. (1997) 'The rise and fall of highbrow snobbery as a status marker', Poetics 25(23): $75-92$.

Peterson, R. A. (2005) 'Problems in comparative research: The example of omnivorousness', Poetics 33(5-6): 257-282.

Peterson, R. and Kern, R. (1996) 'Changing highbrow taste: From snob to omnivore', American Sociological Review 61(5): 900-907.

Prieur, A. and Savage, M. (2011) 'Updating cultural capital theory: A discussion based on studies in Denmark and in Britain', Poetics 39(6): 566-580. 
Prior, N. (2005) 'A Question of Perception: Bourdieu, Art and the Postmodern', The British Journal of Sociology 56(1): 123-39.

Purhonen, S., Heikkilä, R., Karademir-Hazir, I. (2017) 'The grand opening? The transformation of the content of culture sections in European newspapers, 1960-2010', Poetics 62: 29-42

Robins, K. and Aksoy, A. (2000) 'Deep Nation: The National Question and Turkish Cinema Culture', in Hjort M. and Mackenzie S. (eds.) Cinema and Nation. London and New York: Routledge, pp. 191-208.

Roose, H., Van Eijck, K. and Lievens, J. (2012) 'Culture of distinction or culture of openness? Using a social space approach to analyze the social structuring of lifestyles', Poetics 40(6): 491513.

Sarmaşık [Ivy] (2015) [Film] TolgaKaraçelik (dir). Cine Chromatixet. al.

Suner, A. (2011) 'Between magnificence and monstrosity: Turkishness in Recent PopularCinema' New Perspectives on Turkey, 45:123-154.

Tudor, A. (2005) 'The rise and fall of the art (house) movie', in D. Inglis and J. Hughson (eds) The sociology of art: Ways of seeing. Basingstoke, England: Palgrave, pp. 125-138.

Van Eijck, K. and Knulst, W. (2005) 'No more need for snobbism: Highbrow cultural participation in a taste democracy', European Sociological Review 21(5): 513-528.

Varriale, S. (2016) Globalization, music and cultures of distinction: the rise of pop music criticism in Italy. London: Palgrave.

Verboord, M. (2014) The impact of peer-produced criticism on cultural evaluation: A multilevel analysis of discourse employment in online and offline film reviews. New Media \& Society 16: $921-940$ 